\title{
Articles
}

\section{Missionary Society Archives and Research on Sino-Western Cultural Exchanges*}

\author{
SU Ching ${ }^{\dagger}$
}

\section{Introduction}

From the 1790s the Protestant missionary societies of Western nations continuously sent missionaries to the countries of the world to propagate Protestant Christianity. If we look at just China alone, we find that from 1807, when the first Protestant missionary arrived in China, to 1905, a century later, the number of missionaries in China increased to 3,445 , and the number reached an all-time high of 8,158 missionaries in $1925 .{ }^{1}$

Protestant missionaries were not only numerous, but also engaged in a number of activities besides proselytizing. They established schools and taught. They printed and published. They founded hospitals and treated the sick. And they translated. Through these other activities they became an important conduit for Sino-Western cultural exchange and had a tremendous influence on China. All the while, they sent back to their sponsoring missionary societies letters, journals, reports, and forms, in which they expressed their thoughts, their ways of managing, and their sundry observations and understandings of China. Because the missionary societies preserved these materials, with the passage of time these collections became vast archives. Today they serve as a valuable treasury of first-hand historical materials for studying Sino-Western cultural exchanges. We can use these materials not only to supplement and correct omissions and errors in the second-hand literature, but also to help reconstruct historical facts in detail and objectively explain the significance and influence of various sorts of

* This paper was originally presented as a keynote speech at the Eighth Annual Meeting of the Society for Cultural Interaction in East Asia, May 7, 2016.

$\uparrow$ Retired professor, Institute for China Studies, National Yunlin University of Science and Technology.

1 Donald MacGillivrary, ed., A Century of Protestant Missions in China (1807-1907) (Shanghai: American Presbyterian Mission Press, 1907), p.674. Stephen Neill, A History of Christian Missions (London: Penguin Books, 1986), p.429. 
cultural exchanges.

Because there are so many missionary archives and their collections are so diverse, I will here limit myself to the Chinese sections of the European and American archives that I have used. I will discuss five areas-proselytizing, establishing schools and teaching, founding hospitals and treating the sick, translating, and printing and publishing-giving concrete examples, along with illustrations of archives, in order to show the importance of the historical materials in missionary archives for the study of Sino-Western cultural exchange.

\section{Proselytizing}

Robert Morrison's first day in China In as much as Protestant missionaries were the conduit of Sino-Western cultural exchange, the thoughts and actions of Robert Morrison, the first Protestant missionary to set foot in China, have a symbolic and historic significance in the history of such cultural exchange. For instance, on September 4, 1807, the first day he set foot in China, what were his thoughts, what did he do, and what sort of reactions did he provoke? Memoirs of the Life and Labours of Robert Morrison, edited and published by his wife after he passed away, is the authoritative work on Morrison, and most researchers rely on it as their source of information about Morrison. ${ }^{2}$ But this memoir begins its coverage of his stay in China with his arrival at Guangzhou on September 7, the fourth day of his stay in China. It is as if he thought nothing and did nothing on his first three days in China.

This, however, was not the case. In the London Missionary Society Archives is a journal entry for September 4, 1807, which he wrote at an inn in Macau at 10 p.m. after he had landed. ${ }^{3}$ There are also entries for the following few days recording in detail his thoughts and activities for the day. These journal entries are valuable records for the history of Sino-Western cultural exchange that can supplement serious omissions in Memoirs of the Life and Labours of Robert Morrison. They also show that the first three days of Protestant Christianity's presence in China were not a complete blank.

A chronology of Cai Gao's life While omissions in second-hand historical sources are bad enough, even worse are falsified historical materials. In the China Mission Yearbook 中華基督教會年鑑, no.7 (1924), there is a biography

2 Eliza A. Morrison, Memoirs of the Life and Labours of Robert Morrison (London: Longman, Orme, Brown, Green, and Longmans, 1839).

3 London Missionary Society Archives, China, South China, Journal, Robert Morrison, 4 September 1907. 
of China's first Protestant Christian, Cai Gao 蔡高. Appended to this biography is a chronology of his life, signed by two authors, stating that Cai Gao, when he was 59 (1846), was imprisoned for his belief in Protestant Christianity, and that on the 3rd of the Sixth Month he died as a martyr for his beliefs. ${ }^{4}$

However, much earlier, on October 12, 1818, John Slater, a missionary for the London Missionary Society in Guanzhou, wrote a letter to the secretary of the society stating at the end of his letter that Cai Gao, whom Morrison had baptized several years earlier, had died a few days before. ${ }^{5}$

One year later, on November 14, 1819, Morrison stated in a letter that the Chinese authorities sent officers to the dormitory of the East India Company to arrest a man. That man was none other than the younger brother of the man whom he had baptized but who had already died. ${ }^{6}$ When Morrison wrote his letter, he had baptized only one individual, Cai Gao, who had already died. The letters of Slater and Morrison thus show that the abovementioned chronology stating that Cai Gao lived to 1846 was fabricated.

Documents on Liang Fa Mingled in with English documents in the archives of missionary societies are quite a few Chinese documents, often having unexpected historical value. For instance, there is the diary that Liang Fa 梁 發, the first Chinese evangelist, kept from March to November 1830. In it he notes that he and his assistant $\mathrm{Qu}$ Ang 屈昂 carried out a unique method of spreading the gospel. They would follow the Guandong provincial education commissioner 學政 on his rounds to examinations for the Cultivated Talent degree 秀才 and the Confucian Apprentice status 文童, and outside the exam sites they would distribute christian books to the candidates. On a single day, they might give out tens to hundreds of books. ${ }^{7}$ The historical value of these records is that they confirm that when Hong Xiuquan 洪秀全, leader of the Taiping Rebellion 太平天國, took the civil-service examination in Guangzhou in the 1830s, he received Good Words to Admonish the Age 勸世良言, read it,

4 “Cai Gao fu nianpu” 蔡高附年譜 (A Chronology of Cai Gao's Life), Zhonghua Jidujiaohui nianjian 中華基督教會年鑑 (China Mission Yearbook), edited by Zhonghua Quanguo Jidujiao Xiejinhui 中華全國基督教協進會, no.7 (1924): 164-167.

5 London Missionary Society Archives, Ultra-Ganges, Malacca, box 1, folder 3, jacket A, John Slater to W. A. Hankey, Canton, 12 October 1818.

6 London Missionary Society Archives, China, South China, box 2, folder 1, jacket B, R. Morrison to George Burder, Canton, 14 November 1819.

7 London Missionary Society Archives, China, South China, box 3, folder 1, jacket A, R. Morrison to W. A. Hankey, Canton, 14 November 1830, and R. Morrison to Joseph Arundel, Canton, 15 November 1830, enclosure. In his letters from 1830 to 1832, Morrison frequently gave daily reports of Liang Fa's distribution of missionary books. 
experienced a revolution in thinking, and went on to lead the first large-scale rebellion of against the Qing dynasty. ${ }^{8}$

In 1834 Liang Fa, because he was sought for arrest by the local authorities for again distributing books during the Guangdong provincial examinations, fled to Southeast Asia for five years. There too he continued distributing books to Chinese. In the London Missionary Society Archives is a detailed list, written by Liang Fa in 1839, of books distributed to trading ships from throughout China docking in Singapore. This list records dates, the number of ships, the name of each ship, the origin of each ship in China, the name of each ship's captain, etc. ${ }^{9}$ And yet there is no evidence showing that any of these ship captains or sailors were nearly as influenced by the christian books as Hong Xiuquan.

\section{Establishing Schools and Teaching}

Protestant missionaries were an important element in promoting the modernization of Chinese education. In China they established many schools at all levels. Researchers for the most part have focused only on universities, but missionary society archives in fact contain more documents on elementary and middle schools.

The Anglo-Chinese College at Malacca On the Anglo-Chinese College at Malacca, a well-known school in the history of modern Sino-Western cultural exchange, an excellent monograph titled Waiting for China appeared in 1979. ${ }^{10}$ Yet this book makes some statements that still bear discussing. For instance, Brian Harrison, after devoting over a page to discussing the student Yuan Dehui 袁德輝 (Shaou Tih 小德), says that there is evidence that Yuan Dehui translated notices into English for Lin Zexu 林則徐, the imperial commissioner 欽差大臣 who led the campaign to suppress the opium trade, and that the missionary James Legge, before criticizing the Anglo-Chinese College as having never produced any translators, should look at the fine example of Yuan Dehui. ${ }^{11}$

There are problems with this statement of Harrison's. First, while Yuan

8 Liang Afa 梁阿發, Quan shi liang yan 勸世良言 (Good Words to Admonish the Age), 9 vols. (Guangzhou: Religious Tract Society, 1832).

9 London Missionary Society Archives, Ultra Ganges, Singapore, box 2, folder 1, jacket C, Alexander \& John Stronach to William Ellis, Singapore, 14 May 1839, enclosure, “List of Ships Distributing Bibles" 分發大小聖書各船開列.

10 Brian Harrison, Waiting for China: The Anglo-Chinese College at Malacca, 18181843, and Early Nineteenth-Century Missions (Hong Kong: Hong Kong University Press, 1979).

11 Harrison, Waiting for China, p.127. 
Dehui did indeed translate notices for Lin Zexu, the quality was rather lacking, and he used hardly any punctuation, simply adding periods at the ends of paragraphs. And when The Canton Register published his translation of the notice, the editor added a note saying that this was not English, that it was but a use of the Roman alphabet taking on the appearance of a notice. ${ }^{12}$ Moreover, the missionary Samuel W. Williams, who was also in China at the time, criticized Yuan Dehui as having insufficient grasp of both Latin and English and being able to understand only broad outlines of meanings. ${ }^{13}$

Second, the statement that the Anglo-Chinese College has never produced any translators, uttered in 1843, came not from Legge but from Henry Pottinger, the British commander in chief during the Opium War (1839-1842) and the governor of Hong Kong after the war. After Legge had already moved the Anglo-Chinese College from Malacca to Hong Kong, he unexpectedly discovered that Pottinger had canceled the monthly subsidy that the East India Company had given the college. Legge asked that it be reinstated. But Pottinger, in a letter of reply, said that during the war, the British army could not find any qualified translators in Malacca or anywhere else, and that canceling the subsidy was quite appropriate. ${ }^{14}$

English instruction Most people think that church schools invariably teach English, and that students of these schools are quite proficient in English. Documents in missionary society archives show that this was not always true. After the Opium War, some schools founded by missionaries intentionally got rid of English instruction. For example, when the Ningbo mission of the Presbyterian Church in the U.S.A. founded a boarding school, the missionaries vigorously discussed whether to offer English instruction, they established an ad hoc committee to study the matter, and the committee produced a more-than-twenty-page report presenting pros and cons. Finally, the missionaries suggested not teaching students to read English, and the mission decided not to teach English. ${ }^{15}$ A year later the mission reviewed this decision and reaffirmed that this was the correct decision. ${ }^{16}$

12 Canton Register, July 30, 1839, p.136.

13 Chinese Repository, March 1842, p.160.

14 London Missionary Society Archives, China, South China, box 4, folder 3, jacket B, LMS Missionaries to Sir Henry Pottinger, Hong Kong, 18 August 1843, enclosure, "Copy of Sir Henry's answer to the above letter, 21 Aug 1843."

15 Presbyterian Church in the U.S.A., Board of Foreign Missions, Correspondence and Reports, 1833-1911, China, Incoming, vol.2, no.106, Minutes of the Annual Meeting of the Ningpo Mission, September 10, 1845; no.127, Report of the Committee on English Instruction, 1845; and no.132, Walter M. Lowrie to Walter Lowrie, Ningpo, 31 December 1845.

16 Presbyterian Church in the U.S.A., Board of Foreign Missions, Correspondence and 
Some missionary societies even adopted policies of not teaching English. For instance, Rufus Anderson, secretary for the American Board of Commissioners for Foreign Missions, wrote a letter in 1849 to all of its missionaries in China instructing them on four matters concerning school instruction. The third matter was that they should not teach Chinese students English. ${ }^{17}$

The Shanghai boarding school of the London Missionary Society, established in 1849, also did not teach English. Article 5 of the school's regulations stipulated that student instruction should be carried out entirely in Chinese. ${ }^{18}$ But with increasing contacts between Chinese and Westerners in all sorts of fields, there was a great increase in the need for Chinese proficient in English. The missionary William Muirhead, headmaster of the London Missionary Society boarding school at Shanghai, took out an advertisement in the Shanghai News 上海新報 in which he stated that the newly founded British School 大英學堂 sought students desiring to study only British English. ${ }^{19}$ The times had changed. In the past, missionary authorities feared that Chinese students, once they became proficient in English, would be lured away from the church to enter commerce (particularly, the violent opium trade). Now they thought that only by offering English could they attract more students.

Even so, we should not overgeneralize and state that from then on all church schools taught English. For example, as late as 1899, J. E. Shoemaker, a Presbyterian missionary in Ningbo, stated that his school went along with the trend of the times and began offering English instruction, only to find after three years that students had not become competent in either Chinese or English. Hence, the school decided to follow its former practice and thus to eliminate English and teach only in Chinese. ${ }^{20}$

Female education The motives and goals of nineteenth-century mission-

Reports, 1833-1911, China, Incoming, vol.2, no.144, W. M. Lowrie to W. Lowrie, Ningpo, May 30, 1846; and no.167, Ningpo Mission, "Third Annual Report of the Ningpo Mission," October 1, 1846.

17 Papers of the American Board of Commissioners for Foreign Missions, Unit 1, ABC 2.1, vol.11, Rufus Anderson to the Brethren of the Canton Mission, Boston, December 31, 1849.

18 London Missionary Society Archives, China, Central China, box 1, folder 2, jacket B, William C. Milne to A. Tidman, Shanghai, 13 February 1849.

19 “Chuantou huojia zhi” 船頭貨價紙 (News on Prices for Ship Captains), Shanghai Xinbao 上海新報, no.356 (2nd of the Seventh Month, 1864).

20 Presbyterian Church in the U.S.A., Board of Foreign Missions, Correspondence and Reports, 1833-1911, China, Incoming, vol.39, no.76, J. E. Shoemaker to Robert E. Speer, Ningpo, December 29, 1899. 
aries in China in giving education to girls will perhaps surprise us. In 1839 Ira Tracy, a missionary of the American Board of Commissioners for Foreign Missions, stated that a strong motive for giving education to girls was to provide future wives for the boys of the mission school.21

The 1863 annual report for the Ningbo Presbyterian mission stated that one should not underestimate the value of the mission's boarding school for girls, because the girls of the school are the future wives of China mission assistants and a source of teachers for day schools for girls. ${ }^{22}$ Even as late as 1876, the secretary of the Presbyterian Church wrote a letter to a missionary in Ningbo, solemnly declaring that the main work of the school for girls was to cultivate wives for Chinese ministers and evangelist. ${ }^{23}$

In the Missionary Society Archives are many more examples of this type of thinking and doing. As one can see, this type of thinking was rather widespread among nineteenth-century missionaries in China. They provided education to girls to cultivate wives for their Chinese male converts, not to cultivate women capable of independence and self-development.

\section{Founding Hospitals and Treating the Sick}

Also contained in missionary society archives are documents on missionaries' efforts at treating the sick. Here too these documents can be used to supplement and correct the omissions and errors of other historical sources. Below I give three examples.

The reason that Peter Parker was sent to China The first missionary physician to come to China was Peter Parker. He was sent by the American Board of Commissioners for Foreign Missions, and he arrived in China in late October 1834. Why did the board send him? Neither studies nor biographies of Parker give a clear reason. Even the classic study Peter Parker and the Opening of China, by Edward V. Gulick, simply states that Rufus Anderson, secretary for the American Board of Commissioners for Foreign Missions, said to Parker that the board needs men like him to go to China to serve as missionaries. ${ }^{24}$

21 Papers of the American Board of Commissioners for Foreign Missions, Unit 3, ABC 16.2.4, vol.1, Ira Tracy to R. Anderson, Singapore, January 4, 1839.

22 Presbyterian Church in the U.S.A., Board of Foreign Missions, Correspondence and Reports, 1833-1911, China, Incoming, vol.4, no.397, "Twentieth Annual Report of the Ningpo Mission for the Year Ending October 1, 1863."

23 Presbyterian Church in the U.S.A., Board of Foreign Missions, Correspondence and Reports, 1833-1911, China, Outgoing, vol.65, no.49, W. W. Eddy to Miss Harshberger (Ningpo), New York, June 26, 1876.

24 Edward V. Gulick, Peter Parker and the Opening of China (Cambridge, Mass.: Harvard University Press, 1973), p.11. 
In fact, the Papers of the American Board of Commissioners for Foreign Missions show that Parker was sent to China at the urgent request of Elijah C. Bridgman, another American Board of Commissioners missionary, already in China. On the basis of his observations and experience in China, Bridgman, in a letter dated July 1, 1833, urged the board to send a physician. Later, in letters dated March 4 and July 14, 1834, he repeated this request. ${ }^{25}$ But before the board received Bridgman's second letter, it had already decided to send Parker to China.

The nature of Renji Hospital We can also make use of mission society archives to clarify another historical fact about modern Western medicine in China, namely, the connection between Renji Hospital 仁濟醫院 in Shanghai and the London Missionary Society. Renji Hospital was founded in 1844 by William Lockhart, a missionary physician for the London Missionary Society. From then until 1950, over a hundred years, the hospital was managed for the most part by society physicians. Hence, nearly all books on the hospital regard it as a missionary hospital, a church hospital, or a London Missionary Society hospital.

But such a description of the hospital is inaccurate. In a letter dated October 14, 1846, Lockhart clearly stated that the recently completed Renji Hospital does not belong to the London Missionary Society, that it was built from funds donated by foreigners living in Shanghai, that donors made up the board of directors, but that the hospital would be managed by society physicians. ${ }^{26}$ However, problems arose during 1865 and 1866. Relations between Renji Hospital and the London Missionary Society took a turn for the worse, and the trustees of the hospital canceled the agreement of cooperation with the society and had the hospital managed by foreign physicians living in Shanghai. ${ }^{27}$ This arrangement lasted until the close of the nineteenth century. Then in 1904 the trustees again signed an agreement of cooperation with the London Missionary Society, and the society sent the missionary physician Cecil J. Davenport to manage the hospital. ${ }^{28}$ Hence, from 1868 to 1904 , a

25 Papers of the American Board of Commissioners for Foreign Missions, Unit 3, ABC 16.3.8, vol.1, Elijah C. Bridgman to R. Anderson, Canton, July 1, 1833, March 4, 1834, and July 14, 1834.

26 London Missionary Society Archives, China, Central China, box 1, folder 1, jacket C, Walter H. Medhurst \& William Lockhart to the Directors, Shanghai, 14 October 1846.

27 London Missionary Society Archives, China, Central China, box 3, folder 2, jacket B, James Johnston \& R. Maclean to A. Tidman, Shanghai, 2 September 1865; box 3, folder 2, jacket C, William Muirhead to A. Tidman, Shanghai, 22 May 1866; and box 3, folder 2, jacket C, W. Muirhead to Joseph Mullens, Shanghai, 20 July 1866. London Missionary Society Archives, China, Central China, box 15.1, folder H, jacket 
total of thirty-six years, Renji Hospital had no connection with the London Missionary Society. So for this reason as well, we cannot say Renji Hospital was a London Missionary Society hospital.

Materials on Huang Kuan Huang Kuan 黃寬 (Wong Fun) is an important figure in the history of Sino-Western cultural exchange. Together with Yung Wing 容閶, he studied abroad in the United States. After finishing middle school, he went to the University of Edinburgh in Britain to study medicine. After graduating, he received an appointment from the London Missionary Society as a missionary physician and returned to China. The London Missionary Society Archives has quite a few historical documents by him. For instance, on November 26, 1857, he reported in a letter from Hong Kong circumstances regarding the practice of medicine, including the number of patients per month and the average number of patients per day. ${ }^{29}$ Toward the end of 1858 he moved to Guangzhou, and up until he left missionary service late in 1860 , he wrote some ten letters reporting on his practice of medicine. Unfortunately, only few researchers make use of these first-hand reports written by Huang Kuan.

Worth noting is that the authoritative History of Chinese Medicine, by Wang Jimin and $\mathrm{Wu}$ Liande, states that Huang Kuan died on October 12, 1878. ${ }^{30}$ But Benjamin C. Henry, a Presbyterian missionary familiar with Huang Kuan and in Guangzhou at the time, wrote a letter to the missionary physician J. G. Kerr, who was on leave in the United States, stating that Huang Kuan died on October 10, only two days before Henry wrote his letter. ${ }^{31}$ For the date of Huang Kuan's death, Henry's letter is more reliable than the History of Chinese Medicine. Between the two dates given for Huang Kuan's death, there is only a difference of two days, but this slight difference reveals the different uses of first-hand and second-hand historical materials.

\section{Translating}

Translation is an important part of Sino-Western cultural exchange, and nineteenth-century missionaries in China ardently engaged in it. Hence, there are many historical materials related to translation in missionary society

L1, Willett Bevan to R. Wardlaw Thompson, Shanghai, April 28, 1904.

29 London Missionary Society Archives, China, South China, box 6, folder 1, jacket A, Wong Fun to A. Tidman, Hong Kong, 26 November 1857.

30 Wang Jimin (K. Chimin Wong) and Wu Liande (Wu Lien-Teh), History of Chinese Medicine, 2nd ed. (Shanghai: National Quarantine Service, 1936), p.395.

31 Presbyterian Church in the U.S.A., Board of Foreign Missions, Correspondence and Reports, 1833-1911, China, Incoming, vol.14, no.124a, Benjamin C. Henry to J. G. Kerr, Canton, October 12, 1878. 
archives.

Robert Morrison's translation manuscripts Protestant missionaries could proselytize in China because they had translations. At the meeting of the board of directors of the London Missionary Society on July 30, 1804, a letter from the Rev. William W. Moseley was read aloud. In this letter he suggested that the society translate the bible into Chinese and begin proselytizing in China. The board resolved that it was important to translate the bible into Chinese, decided to send a missionary to China to carry out the translation, and hoped that Robert Morrison could undertake the translation. ${ }^{32}$ Thus began the Protestant effort to proselytize in China.

Morrison's translation of the bible has attracted much attention from researchers of later ages, but these researchers overlook one important aspect of the translation, namely, that in preparing to translate the bible, he practiced translating many styles of Chinese into English. Some of these practice translations have been published, but there are also many translations in manuscript form waiting in the archive for researchers to discover them, such as Laozi's Texts on Treatise on Action and Retribution 太上感應篇, Divine Lord Wenchang's Ten Precepts of the Window Overlooking the Banana Tree 文昌帝君蕉窗十訓, and portions of the Analects 論語 and Dream of the Red Chamber 紅樓夢. In the past, scholars have thought that the earliest translation of even a portion of the Dream of the Red Chamber was John Francis Davis's translation of portions of chapter 3, published in 1830. In fact, in 1813 Morrison translated chapter 4 and wrote an introduction. ${ }^{33}$ Thus, one can see that Morrison had a deep appreciation of this novel. He also translated the first poem of the collection "Poems on My Fortieth Birthday" 四十生日詩, by Ruan Yuan 阮元 (1764-1849). ${ }^{34}$ Ruan Yuan, governor-general of Guangdong and Guangxi residing in Guangzhou, no doubt never imagined that thirteen hongs outside the city wall there resided a foreigner who would translate his poem into a foreign language.

The Macau News translators When missionaries began translating, they took note of Chinese translation activity. From 1839 to 1840, when Lin Zexu confronted the British and prohibited the opium trade, in order to gather information and learn about his adversaries he hired four translators to translate English newspapers into Chinese. These translations were collec-

32 London Missionary Society Archives, Board Minutes, 30 July 1804.

33 London Missionary Society Archives, China, South China, box 1, folder 2, jacket A, R. Morrison to G. Burder [?], Macao, 18 January 1811, enclosure.

34 London Missionary Society Archives, China, General, Personal, box 1. 
tively called "Macau News" 澳門新聞紙, but were never published. At that time the missionary physician Peter Parker wrote about this effort in his report on the work of the Guangzhou mission to the American Board of Commissioners for Foreign Missions, and he mentioned the names of the four translators: Aman 阿曼, Shaou Tih 袁德輝 (the above-mentioned student of the Anglo-Chinese College), Alum 阿倫, and Atih 梁進德. ${ }^{35}$ For each translator, Parker gave a brief introduction of one sentence, but because the Chinese literature does not mention them at all, were it not for Parker's introduction, they would have vanished from the stage of history. In The World as Seen by Lin Zexu: “Macau News" in the Original and Translation 林則徐看見的世界: 《澳門新聞紙》的原文與譯文, I discuss these four translators and their work in detail, and I preserve in full the hitherto unknown original text of Macau News. ${ }^{36}$

Historical materials of the Translators College One famous institution in the history of Sino-Western cultural exchange is the Translators College 同文 館, a school for training government translators. The school first began teaching English, and the first instructor was John S. Burdon, of the Church Missionary Society. In the society's archives are documents written by him relevant to the history of Sino-Western cultural exchange. For instance, in a letter of May 28, 1862, he stated that the Office of Foreign Affairs 總理衙門, with help from the British envoy, approved his appointment as an instructor. ${ }^{37}$ But more important is his letter of July 2, 1862, in which he stated the date of the opening of the college, the number of students, the students' ages and family backgrounds, the location of the college, conditions in the classroom, study and break times, his own salary and treatment, etc. ${ }^{38}$ Previous studies of the Translators College have never made any use of these two important letters.

After Burdon, John Fryer and W. A. P. Martin served as English instructors at the Translators College, and they too left documents related to the college. For instance, Fryer, in a letter dated March 8, 1864, expressed dissatisfaction with the fact that when he taught class, a Chinese instructor

35 Papers of the American Board of Commissioners for Foreign Missions, Unit 3, ABC 16.3.8., vol.1A, P. Parker to R. Anderson, Macao, July 4, 1839.

36 Su Ching 蘇精, Lin Zexu kanjian de shijie: “Aomen xinwenzhi” de yuanwen yu yiwen 林則徐看見的世界：《澳門新聞紙》的原文與譯文 (The World as Seen by Lin Zexu: Macau News in the Original and Translation) (Taipei: Sifuzhai, 2016), pp.3-50.

37 Church Missionary Society Archives, C CH O 22, John Shaw Burdon to John Chapman, Peking, May 28, 1862.

38 Church Missionary Society Archives, C CH O 22, J. S. Burdon to J. Chapman, Peking, July 2, 1862. 
was always sitting in the classroom observing and preventing him from proselytizing the students. ${ }^{39}$ Martin, in his 1865 annual report on the Beijing mission of the Presbyterian Church, stated that college regulations expressly prohibited proselytizing. 40

\section{Printing and Publishing}

Missionaries frequently engaged in printing and publishing. Hence, mission society archives have vast amounts of documents on such activities. We can make use of these documents to explore the process whereby missionaries helped to modernize Chinese printing and to fathom the effect and influence of the various sorts of new knowledge that they disseminated with their publications.

The modernization of Chinese printing The first Protestant publication in China was Acts of the Apostles 使徒行傳, printed in 1810 with woodblocks. The characters were rounded, the character grid spacious, and the carving and printing technology high quality. Robert Morrison was quite satisfied with the printing. He even listed the cost of carving the blocks, buying the paper, and printing, which came to 521 yuan in total. He also said that the cost was higher than that for printing ordinary Chinese books. The reason was that he was a foreigner and the printer had to take on additional risk to do this illegal job. Of course the printer would ask for more money. ${ }^{41}$

Because the cost for missionaries to print Chinese materials was high and printing technology was controlled by the Chinese, Morrison stopped favoring woodblock printing and began advocating replacing woodblock printing with Western movable-type printing. Later missionaries accepted this point of view and made efforts to apply Western movable-type technology to Chinese. In the 1860s William Gamble, of the American Presbyterian Mission Press, created six sets of Chinese movable type in different sizes, establishing the technical foundation for the modernization of Chinese printing. Before the close of the nineteenth century, printing with Western-style Chinese movable type had nearly completely replaced Chinese traditional woodblock printing.

A medium for disseminating the new knowledge The effect of the publi-

39 Church Missionary Society Archives, C CH O 38, John Fryer to H. Venn, Peking, March 8, 1864.

40 Presbyterian Church in the U.S.A., Board of Foreign Missions, Correspondence and Reports, 1833-1911, China, Incoming, vol.7, no.242, W. A. P. Martin, "Second Annual Report of the Peking Mission for the Year Ending October 1, 1865."

41 London Missionary Society Archives, China, South China, box 1, folder 2, jacket A, R. Morrison to the Directors, Macao, 7 January 1811. 
cations of the missionaries far and away exceeded their original intent of spreading the gospel. Such Western-style publications became a tool for disseminating the various types of new knowledge. Though most Chinese did not accept belief in Christianity, they readily accepted the new knowledge that the missionaries brought to China. Quite a few books by missionaries enjoyed a ready market. For example, Richard Q. Way's An Outline of Geography 地球說略 was originally intended as a textbook for students. From 1847 to 1856 the book was reprinted four times. The first printing was only 200 copies, but the fourth printing was greatly increased to 9,000 copies. ${ }^{42}$ In 1857, after the fourth print run, copies sold briskly. In 1859 annual sales reached 3,523 copies, leaving only 3,636 copies in the warehouse. ${ }^{43}$ Thus, in just two years the Ningbo Huahua Bible Bookstore 寧波華花聖經書房 sold most of its inventory of this book, the only Chinese book that it sold rather than give away. Because it met Chinese demand, this school textbook became a bestseller among the populace at large.

Another example is A New Treatise on Anatomy 全體新論, by Benjamin Hobson, a missionary physician for the London Missionary Society. This was the first Chinese book to systematically introduce modern medical knowledge. For Chinese readers, this work "revealed the hitherto unseen and discussed the hitherto undiscussed," to borrow from Wang Tao 王鞱, a late Qing translator reformer. ${ }^{44}$ In his 1855/56 annual report for Huiai Hospital 惠 愛醫館, which he managed, Hobson asserted that within five years of the publication of A New Treatise on Anatomy in 1851, he had the work printed twice and Chinese publishers had printed the work from newly carved woodblocks at least three times, that there were more than 10,000 copies in circulation in China, and that this did not include the work's serialization in the Hong Kong monthly Chinese Serial 遐雨貫珍 in 1855.45 Chinese buyers of this book not only used the book themselves, but also gave it to others as a gift. Even some foreigners did this. For example, when Griffith John in October 1858 arrived in Danyang, Jiangsu Province, to spread the gospel, he

42 Presbyterian Church in the U.S.A., Board of Foreign Missions, Correspondence and Reports, 1833-1911, China, Incoming, vol.3, no.46, Report of the Publishing Committee, October 1, 1847, and vol.4, no.96, Report of the Press for the Year Ending September 30th 1856.

43 Presbyterian Church in the U.S.A., Board of Foreign Missions, Correspondence and Reports, 1833-1911, China, Incoming, vol.4, no.242, Report of the Press for the Year Ending October 1st 1859.

44 Wang Tao 王鞱, Wang Tao riji 王塪日記 (Wang Tao's Diary), edited by Fang Xing 方 行 and Tang Zhijun 汤志钧 (Beijing: Zhonghua Shuju, 1987), p.34.

45 B. Hobson, Report of the Missionary Hospital in the Western Suburbs of Canton, under the Care of Dr. Hobson of the London Missionary Society, for 1855-56 (Canton: S. Wells Williams, 1856), p.13. 
gave Hobson's New Treatise on Anatomy to the local official. This official, being delighted with the gift, sent him tea and cakes in return. ${ }^{46}$

How did missionaries promote Western printing technology to replace traditional Chinese woodblock printing? How did these Westerners view their own works? How did they disseminate their works? What was the Chinese reaction to such works? Missionary society archives have many documents useful for answering these and similar questions.

\section{Conclusion}

Research in the history of Sino-Western cultural exchange, like other fields of history, faces two tasks: reconstructing the facts and interpreting the significance and influence of the facts. Reconstructing the facts needs to be based on reliable and authentic historical sources. Only then do we have a foundation for interpreting the facts without getting lost in generalities and errors. Missionary society archives are a treasure-house of first-hand historical materials consisting of the thousands upon thousands of documents left behind by missionaries.

The examples of missionary society archives provided in this paper all have their value for the historical materials that they contain. Some of these documents can supplement the omissions of other materials, some can correct the errors of still other materials, and some are waiting for researchers to discover and use them. I have reaped many rewards from my use of these archives over the years. I am glad to share my experience. Should this experience prove useful to others in the field, this will be my greatest reward.

46 London Missionary Society Archives, China, Central China, box 2, folder 2, jacket B, Griffith John to A. Tidman, Shanghai, 6 November 1858. 